\title{
Antysemityzm i denuncjowanie Żydów we Francji podczas drugiej wojny światowej
}

W naszych społeczeństwach donosiciel należy do ludzi budzących najgłębszą pogardę. Wyobrażamy sobie, że jest podły, zawistny, zły, bezwartościowy, że siada przy stole w mrocznej jadalni, żeby na byle jakiej kartce papieru pisać donosy na sąsiada albo konkurenta... Istnieje wiele stereotypów donosiciela, ale w rzeczywistości niewiele jest tematów tak trudno uchwytnych dla historyka jak denuncjacja. Historiografia odnosząca się do tego tematu we Francji ${ }^{1}$ praktycznie nie istnieje, a jedynym ogólnym opracowaniem dotyczącym donosicielstwa za czasów okupacji jest książka dziennikarza André Halimiego. W tym opublikowanym po raz pierwszy w roku $1983^{2}$ opracowaniu autor potępia „chciwość”, „zachłanność”, „niegodne postępowanie” „małych ludzi”, którzy donosili. Opierając się głównie na archiwaliach Komisariatu Generalnego Spraw Żydowskich (Commissariat général aux questions juives, CGQJ)3 , czyli antyżydowskiej placówki rządu Vichy, powołanej wiosną 1941 r., szacuje, że w latach 1940-1944ㄴ wysłano do władz od 3 do 5 mln donosów.

${ }^{1} \mathrm{~W}$ przeciwieństwie do zagranicy, gdzie temat ten poruszany jest od trzydziestu lat, szczególnie w odniesieniu do nazistowskich Niemiec i Związku Radzieckiego. Por. zwłaszcza opracowanie ogólne i demaskatorskie Accusatory Practice. Denunciation in Modern European History 1789-1989, red. Robert Gellately, Sheila Fitzpatrick, Chicago: University of Chicago Press, 1997 (pierwotnie numer specjalny pisma „Journal of Modern History” z grudnia 1996), a także: Gisela Diewald-Kerkmann, Politische Denunziation im NS-Regime oder die kleine Macht der Volksgenossen, Bonn: Dietz, 1995; Mimmo Franzinelli, Delatori: spie e confidenti anonimi: l'arma segreta del regime fascista, Milano: Mondatori, 2001; szerzej na ten temat, przy analizie donosicielstwa z uwzględnieniem tematów skarg wnoszonych do władz, a z drugiej strony - szantażu zob. François-Xavier Nérard, Cinq pour cent de la vérité. La dénonciation dans l'URSS de Staline (1928-1941), Paris: Tallandier, 2004; Jan Grabowski, „Je le connais, c'est un Juif!”. Varsovie 1939-1943. Le chantage contre de Juifs, tłum. Xavier Chantry, Paris: Calmann-Lévy, 2008 (wyd. oryg. „Ja tego Żyda znam!”. Szantażowanie Żydów w Warszawie 1939-1943, Warszawa: Wydawnictwo IFiS, 2004).

${ }^{2}$ André Halimi, La Délation sous l'Occupation, Paris: Alain Moreau, 1983.

${ }^{3}$ Istotne błędy w tej sprawie popełniono na przykład w opisie uprawnień i inicjatywy legislacyjnej CGQJ.

${ }^{4}$ Autor, nie przywołując odpowiednich cytatów, opierał się na artykule zamieszczonym w „Historia” z roku 1975, gdzie napisano, że wszystkie niemieckie służby „żywiły się anonimami. Mówiło się o trzech milionach nich”. Richard Grossmann, Les gestapistes français, 
Donosicielstwo na ziemiach okupowanych jawi się zatem jako zjawisko masowe, materializujące się w listach, na ogół zresztą anonimowych, a dotyczących Żydów, którzy byli prześladowani przez władze niemieckie i rząd francuski.

Rzeczywistość była o wiele bardziej złożona. Wbrew powszechnym przekonaniom, w liczbach bezwzględnych Żydzi nie należeli do głównych ofiar denuncjowania w latach okupacji. Jest to logiczne, skoro stanowili niespełna 1 procent populacji zamieszkującej wówczas Francję (około 300 tys. osób z $40 \mathrm{mln}$ ). Natomiast proporcjonalnie to oni byli zapewne najczęściej atakowaną grupą ${ }^{5}$. Propaganda i działania polityczne, a także liczba dotyczących ich zakazów (takich jak niemieckie przepisy, nakazujące w strefie północnej noszenie żółtej gwiazdy, a także liczne zakazy przebywania w miejscach publicznych, odrębna godzina policyjna itd.) stanowiły czynniki sprzyjające częstym denuncjacjom. Co ważne, głównie w regionie paryskim działały specjalne jednostki policji, których zadaniem było systematyczne sprawdzanie donosów wysyłanych do władz, do armii niemieckiej oraz do antysemickich gazet.

Do lata 1943 r. francuska policja ściśle współpracowała z Niemcami, uczestnicząc w starannym przygotowywaniu łapanek i wcielaniu w życie polityki deportacji cudzoziemców pochodzenia żydowskiego oraz bezpaństwowców. Potem, gdy rząd marszałka Philippe’a Pétaina sprzeciwił się zbiorowemu pozbawieniu obywatelstwa, które miało objąć pewne kategorie francuskich Żydów, władze niemieckie postanowiły uderzyć w całą społeczność żydowską. Większość Żydów żyła wówczas w ukryciu lub/i pod przybraną tożsamością. Z punktu widzenia władz denuncjacja stała się więc podstawowym narzędziem walki z Żydami, umożliwiała bowiem ich demaskowanie. „Po masowych obławach na Żydów w lipcu tego roku indywidualne aresztowania jeszcze się nasiliły. W większości wypadków zatrzymanych Żydów denuncjowali sąsiedzi. Anonimowe listy pisane są drukowanymi literami” - czytamy w notatniku prefekta paryskiej policji zapis z grudnia $1943 \mathrm{r}^{6}$

Od wiosny 1942 do lata 1944 r. deportowano z Francji około 76 tys. Żydów: 42 tys. w 1942 r., 19 tys. w 1943 r., 15 tys. w 1944 r. Wśród zatrzymanych w 1943, a przede wszystkim w $1944 \mathrm{r}$. około połowy stanowili schwytani w regionie paryskim, na ogół wskutek denuncjacji. Poza CGQJ także inne struktury niemieckie i francuskie specjalizowały się w tropieniu Żydów, na przykład Wydział do spraw żydowskich Policji Śledczej w paryskiej Prefekturze Policji, powołany w listopadzie 1942 r., który rozpoznał od 2000 do 3000 donosów przekazanych na specjalnych listach przez Wydział do spraw żydowskich gestapo?

\footnotetext{
„Historia”, seria „La collaboration”, 1975, nr specjalny 39. André Halimi rozszerza te ryzykowne szacunki, obejmując nimi francuską policję i mówi o nawet pięciu milionach donosów...

${ }^{5}$ Por. Laurent Joly, 20000 lettres antisémites, „L'Histoire”, wrzesień 2009, nr 234.

${ }^{6}$ Maurice Toesca, Cinq ans de patience (1939-1945), Paris 1975, zapis z grudnia 1943 r., s. 184.

${ }^{7}$ Por. niepublikowane pamiętniki inspektora Wydziału do spraw żydowskich Jacques’a Beugina, „Devoir de mémoire”, 2003, s. 2. O mechanizmie centralizacji donosów w gestapo i ich wykorzystywaniu przez paryską prefekturę por. Archives nationales (dalej AN), Z 6,
} 
Dokumentacja gestapo oraz Wydziału do spraw żydowskich paryskiej prefektury została w znacznej części zniszczona w chwili wyzwolenia. Chcąc opisać i ocenić skalę zjawiska denuncjowania Żydów w latach 1940-1944, trzeba przeprowadzić możliwie dokładną analizę archiwaliów Komisariatu Generalnego Spraw Żydowskich, które zachowały się niemal w komplecie. Najpierw udało mi się odnaleźć pocztę odebraną przez CGQJ, rejestrowaną od stycznia 1942 do sierpnia 1944 r. przez dyrekcję Gabinetu w Paryżu, dzięki czemu można było dokładnie określić liczbę listów anonimowych, otrzymanych i zarejestrowanych jako takie ${ }^{8}$. Następnie zbadałem korespondencję ogólną CGQJ ${ }^{9}$, a przede wszystkim 9000 teczek osobowych założonych przez dyrekcję Gabinetu ${ }^{10}$. Wśród tych teczek niemal 300 dotyczy osób zadenuncjonowanych: 103 zawierają listy donosicieli, których nie rozpatrzono, 184 to donosy, które dały podstawę do wszczęcia śledztwa przez departament policyjny Komisariatu - Sekcję śledczą i kontroli (Section d'enquête et de contrôle, SEC).

Skoncentrowałem się głównie na działalności tego departamentu, który w Paryżu miał niemal nieograniczoną władzę. Od jesieni roku 1942 do wyzwolenia jego inspektorzy aresztowali prawie 900 osób, z czego większość - w wyniku denuncjacji ${ }^{11}$. W rzeczywistości duża część donosów wiązała się z polityką zagarniania majątków żydowskich (te działania dotknęły od 50 do 100 tys. osób). Wymienione źródła dostarczają jednak znikomej wiedzy na ten temat, ponieważ Departament Proaryjskiej Polityki Ekonomicznej CGQJ miał własne biuro korespondencji, a donosy można odnaleźć w pewnym sensie przypadkowo w aktach dotyczących zagarnianych dóbr, trudno więc było wybrać reprezentatywną próbkę z bardzo obfitego materiału. Natomiast w archiwum Centre de documentation juive contemporaine (CDJC - Centrum Współczesnej Dokumentacji Żydowskiej w Paryżu) znajduje się zbiór 106 listów z donosami, które trafiły do różnych służb Komisariatu Generalnego Spraw Żydowskich. Ten właśnie zbiór umożliwił mi wyodrębnienie kilku typów denuncjacji.

Denuncjowanie Żydów - zjawisko występujące na szeroką skalę we Francji tych mrocznych lat - było wytworem polityki narzuconej przez sytuację i władze okupacyjne. Rozmaite środki stosowane przez Vichy oraz władze niemieckie sprawiły,

189, Akta nr 2372, René G., „3. Liste der Juden die sich gegen die Best des Mil. Bef. Frankreich vergangen haben” [3. Lista Żydów, którzy dopuścili się wykroczeń przeciwko dowództwu wojskowemu we Francji], listopad 1942 r.; ibidem, Zeznania Charles’a Permilleux, 9 listopada 1945 r., a także AN, Z 6, 204 ter, Akta nr 25062, Henri Mosser, raport policyjny, 13 II 1945 r.; ibidem, Zeznania Henriego Mossera, 22 I 1946 r.

${ }^{8}$ Nie wszystkie jednak były donosami (często listy zawierały obelgi albo prośby ofiar policji antyżydowskiej) i, oczywiście, trudno zliczyć donosy podpisane, ale adresowane do konkretnej osoby.

${ }^{9} \mathrm{AN}, \mathrm{AJ} 38,3$ do 70.

${ }^{10}$ AN, AJ 38, 152 do 194.

${ }^{11}$ Poza raportami z aresztowań, rozproszonymi w archiwach CGQJ, zdołałem odnaleźć dziesiątki akt, które opieczętowano po wyzwoleniu decyzją sądu, a które zawierały donosy będące podstawą aresztowań i deportacji. Część akt osobowych SEC spalono tuż przed wyzwoleniem. 
że wyodrębniono wiele przestępstw, które dawały powód do złożenia donosu. Lecz ze względu na formy, jakie przyjęło donoszenie (terminologia używana przez donosicieli, metody przekazywania informacji władzom za pośrednictwem ugrupowań i określonych gazet itp.), wpisuje się ono w obraz francuskiego antysemityzmu i w jego historię. Od „doniesienia” o zagrożeniu mającym charakter powszechny („inwazja” Żydów z zagranicy, ich „manipulacje” w interesach, „skandale finansowe” czy też „bezczelność” Żydów itp.) po denuncjowanie jednostki podejrzanej o szkodliwość kontekst okupacji sprzyjał rozbudzaniu wrogości i osobistej nienawiści, umożliwiając ich usprawiedliwianie dobrem ogółu ${ }^{12}$. Tak oto antysemickie hasła i poglądy oraz denuncjowanie Żydów okazały się nierozłączne ${ }^{13}$.

\section{Charakterystyka denuncjacji na ziemiach okupowanych}

Odkąd istnieje władza, zawsze znajdą się ludzie gotowi donosić „władzom” na swych bliźnich. W starożytnej Grecji donoszenie stało się prawdziwym zawodem (sycophantes krytykowani przez Arystofanesa), a za czasów rewolucji francuskiej donoszenie uzasadniane „dobrem publicznym” było zinstytucjonalizowane i wyraźnie odróżniano je od „donosicielstwa”, o ile bowiem „donosicielstwo jest odrażające, [o tyle] donoszenie obywatelskie stanowi cnotę", chwalił się uczeń gazety „Le père Duchesne” (Ojciec Duchesne), który publicznie zadenuncjował dwóch kapłanów ze swojego regionu, „osoby zepsute i szkodliwe” 14 . Z kolei w „L'Ami du Peuple” (Przyjaciel Ludu) Jean Paul Marat przeciwstawiał „denuncjację” rozumianą jako potępienie osoby publicznej, osoby żyjącej tu i teraz, od „donosicielstwa” - anonimowego i oszczerczego ${ }^{15}$.

Różnica między „donosicielstwem” a „doniesieniem obywatelskim” wydaje się jednak niejasna i subiektywna, a historycy badający temat nie wyznaczają ścisłej granicy między tymi dwoma pojęciami. Analizując przykład ZSRR w latach stalinowskich, François-Xavier Nérard opisuje akt denuncjacji jako przejaw „swobody

${ }^{12}$ Luc Boltanski, L’Amour et la Justice comme compétences. Trois essais de sociologie de l'action, Paris: Métailié, 1990, s. 95.

${ }^{13}$ Uwzględniam jednak w tym artykule tylko listy zawierające donosy na osobę lub grupę osób. Dlatego za donos uznaję np. list do CGQJ podpisany przez „grupę Francuzów [sic!], którzy pragną pracować”, a donoszą na żydowskich rzemieślników zamieszkałych przy ulicy du Caire 18-20 w 2. dzielnicy Paryża. Centre de documentation juive contemporaine (dalej CDJC), XXXVIII-108, Anonim wysłany do CGQJ. Natomiast korespondenci, którzy potępiali Żydów za nielegalny handel w Nîmes albo „najazd” na Pau, zostali pominięci.

${ }^{14}$ Bibliothèque nationale de France, List A. Lartige’a, byłego dowódcy batalionu lekkiej piechoty do ministra spraw wewnętrznych, około $1790 \mathrm{r}$.

${ }^{15}$ Christiane Kohser-Spohn, Théories et pratiques de la dénonciation (1789-1793): analyse d'un exemple [w:] Denunziation und Justiz. Historische Dimensionen eines sozialen Phänomens, red. Friso Ross, Achim Landwehr, Tübingen: Edition Diskord, 2000, s. 78. Od rewolucji francuskiej donosiciel ma dwa oblicza - tego, kto informuje władze, na ogół anonimowo, i ,informatora” prasy, niekiedy szantażysty, osobnika chciwego, jakiego możemy spotkać na kartach XIX-wiecznych powieści. 
działania” jednostki. Donosicielstwo jest oznaką niezadowolenia ludu, nad którym muszą panować struktury partyjne i państwowe ${ }^{16}$. Znawca nazistowskich Niemiec Robert Gellately podkreśla, że interes osobisty stanowi główną pobudkę denuncjacji, nawet jeśli godzi ona we „wroga” - Żyda. Zwraca on także uwagę na wypadki instrumentalnego wykorzystywania gestapo przez donosicieli ${ }^{17}$.

Choć czasami władze zachęcają do denuncjacji, na ogół inicjatywa leży po stronie tego, kto jest denuncjatorem ${ }^{18}$. Donosiciel ${ }^{19}$ uprzedza wolę władzy albo - zwłaszcza w sytuacji kryzysu ekonomicznego, wojny albo dyktatury - dąży do wykorzystania tej władzy, by wziąć prywatny odwet, bez względu na to, czy motywacją działania jest ideologia, własny interes, zemsta czy frustracja ${ }^{20}$. Zainteresowany tworzy zawsze pozory działania w imię sprawiedliwości, ale definiuje tę sprawiedliwość na własny sposób. Denuncjator nie aspiruje do roli działającego w imię prawa, ma jednak nadzieję, że instancja, do której się odwołuje, użyje swej władzy dyskrecjonalnej. W roku 1941 „zawodowa” denuncjatorka Germaine L., członkini partii faszystowskiej Mouvement social révolutionnaire (MSR - Rewolucyjny Ruch Społeczny) oraz pracownica Institut d'étude des questions juives (IEQJ - Instytut Badań Kwestii Żydowskiej), pisała: „Nie ograniczam się do zaciekłej walki z Żydami i masonami, zajmuję się także denuncjowaniem szmuglerów z czarnego rynku i bez wytchnienia tropię oszustów. [...] Na zakończenie proszę o podjęcie szybkich działań, zanim będzie za późno, zanim ogromna większość, która cierpi, rozgoryczona, podejmie bunt"21.

${ }^{16}$ Nérard, Cinq pour cent de la vérité...

${ }^{17}$ Donosy na Żydów, takie jak te, które godziły w osoby słuchające zagranicznych stacji radiowych, tylko sporadycznie zawierają jasno wyrażone pobudki emocjonalne (nazistowskie przekonania, uwielbienie dla Hitlera itp.), co wynika z listów analizowanych przez Roberta Gellately'ego (Avec Hitler. Les Allemands et leur Führer, tłum. Pierre-Emmanuel Dauzat, Paris: Flammarion, 2003; wyd. oryg. Backing Hitler: Consent and Coercion in Nazi Germany, Oxford: Oxford University Press, 2001), s. 186-191 i 255-259.

${ }^{18}$ Psychoanalityk Jacques Hassoun uważa, że donosiciel „wierzy we władzę i pokornie jej służy”, „wyprzedza wolę swego Pana. Nigdy nie stawia się na jego miejscu, ponieważ chce, aby władza była traktowana z pełną powagą. Kocha kij swego Pana”, zob. idem, L'hommage du minable à la canaille [w:] La Délation. Un archaïsme, une technique, red. Nicole Czechowski, Jacques Hassoun, Paris: Autrement, 1992, s. 14-15.

${ }^{19}$ Czyli jednostki. Instytucje nie przekazują sobie donosów, ale informacje. Wiele spółek nieruchomości zwracało się wprost do CGQJ o wyznaczenie tymczasowego zarządcy mieszkań porzuconych przez Żydów, którzy uciekli do strefy wolnej i nie uiszczali komornego. Miał on zbyć nieruchomości, uregulować należności i oddać wolne mieszkanie. Por. AN, AJ 38, 801, Sprawy sporne między aryjskimi właścicielami a żydowskimi lokatorami (1941-1942).

${ }^{20} \mathrm{~W}$ czasie okupacji, jak ocenia historyk Marcel Baudot, 50-55 procent denuncjacji spowodowanych było interesem osobistym (także stałych donosicieli), około 40 procent przekonaniami politycznymi, a poniżej 10 procent zemstą. Marcel Baudot, La résistance française face aux problemes de répression et l'épuration, „Revue d'histoire de la Deuxième Guerre mondiale”, styczeń 1971, nr 81, s. 45.

${ }^{21}$ AN, F 7, 14958, List Germaine L. z 2 VIII 1941 r. 
Za okupacji wielu donosicieli pisało do rozmaitych służb niemieckich i francuskich, wykorzystując sytuację polityczną oraz podział władzy i wymuszając na wszystkich tych, do których się zwrócili, reakcję prowadzącą do zaspokojenia żądzy zemsty: „Pragnę poinformować o niejakim Apterze Armandzie, który zdjął żydowską odznakę i nadal pracuje; [...] nie mogę powiedzieć nic więcej, reszta należy do was, nie ma powodu przymykać oczu na groźnych komónistów [sic!], a zamykać niewinnych. List tej samej treści pżesyłam [sic!] jednocześnie do Komendantury”22. Nierzadko autor donosu bywał nachalny. Po wysłaniu pisanego odręcznie listu donosiciel odczekiwał pewien czas i wysyłał kolejny, bardziej „oficjalny”, ,administracyjny”, czasem pisany na maszynie. Jeśli go nie podpisywał, to z obawy, że list nie wywoła oczekiwanego skutku, i niezręcznie się usprawiedliwiał: „przepraszam, że nie podpisuję tego listu, pracuję jednak u przyjaciół tej kobiety i obawiam się niedyskrecji. Muszę zarabiać na życie. Proszę zbadać tę sprawę i przekonać się, że nie kłamię" - pisała jedna $z$ donosicielek ${ }^{23}$, a pewien dekarz, denuncjując sąsiada komunistę, wysłał po pierwszym, anonimowym liście adresowanym do prefekta policji w Paryżu drugi, tym razem podpisany: „Dziś podpisuję list, licząc, że dochowa pan tajemnicy zawodowej, choć nie mam powodu do żadnych obaw o prawdziwość tego, o czym pana poinformowałem"24.

Wbrew powszechnemu wyobrażeniu o donosicielach jako mało wartościowych i prymitywnych ludziach, denuncjacja nie ominęła żadnego ze środowisk społecznych i dotyczyła nawet elit. Maurice François-Brajon, były członek rady narodowej Fédération républicaine (Federacja Republikańska), pisał do komisarza generalnego do spraw żydowskich Xaviera Vallata (członka tejże partii w latach trzydziestych): „Choć nie kierują mną żadne osobiste ambicje polityczne, uważam za swój obowiązek poinformować Pana o zagrożeniu, jakie stanowi dla dzieła Marszałka Pétaina i polityki admirała Darlana obecność w departamencie Vosges byłych wysokich funkcjonariuszy Frontu Ludowego, a także niejakiego Charles’a Weilla, Żyda, w kantonie Raon l'Étape"25. Dodajmy, że Charles Weill był merem Raon l’Étape, a François-Brajon kilka lat wcześniej bezskutecznie starał się o ten urząd.

Donosicielstwo może przybierać rozmaite formy. Osławione „anonimy” wiążą się z okresem okupacji, ale pomijając fakt, że duża część listów, jak się przekonamy, jest podpisana, donosy składa się nie tylko na piśmie. Przeciwnie - im bardziej totalitarne państwo, tym więcej donosów ustnych ${ }^{26}$. We Francji władze okupacyjne,

${ }^{22}$ Archiwum Prefektury Policji w Paryżu, 77 W 35, 99052, Armand Apter, donos, wrzesień 1941 r. Z archiwów CGQJ wynika, że te same osoby pisały do SEC, do prefektury i gestapo. Toteż niekiedy zanim SEC podjęła działanie, ofiara była już aresztowana, por. na przykład AN, Z 6, 1387, teczka 39, Raport SEC z 1 IX 1943 r.

${ }^{23}$ AN, AJ 38, 160, Akta Ziny B., Anonim z 20 X 1943 r.

${ }^{24}$ AN, Z 6, 165, 2244, Édouard T., Listy do prefektury, 10 VII i 29 VIII $1941 \mathrm{r}$.

${ }^{25}$ AN, AJ 38, 193, Akta Charles’a Weilla, List François-Brajona do Vallata, 26 V 1941 r.

${ }^{26}$ Przekazane ustnie w biurze partyjnym przez obywatela, a następnie zrelacjonowane wymiarowi sprawiedliwości itd., aż do skazania niewinnego na podstawie zeznań ustnych. Działo się tak w ZSRR i w Niemczech, gdzie trybunał ludowy sądził od 1931 r. przeciwników 
milicja czy Komisariat Generalny Spraw Żydowskich posługiwały się „informatorami” i wykorzystywały wszelkie informacje ustne, które udało się zebrać. Wiadomo na przykład, że wielu obywateli dzwoniło bezpośrednio do biura SEC w Paryżu. Również do wielu aresztowań przeprowadzonych z inicjatywy departamentu policyjnego CGQJ przyczyniali się „informatorzy”, szczególnie z dzielnic Belleville i Marais ${ }^{27}$.

Trudno uznać za historyczne nieporozumienie fakt, że okres okupacji kojarzy się z donosicielstwem. Jest oczywiste, że władza, która wystawia pewne kategorie obywateli na społeczną nienawiść (wrogowie marszałka Pétaina, „gaulliści”, Żydzi, komuniści, „terroryści”, osoby uchylające się od przymusowych robót w Rzeszy), tworzy warunki skłaniające innych do denuncjowania. Kontekst historyczny lat 1940-1944 sprzyjał donosom, zwłaszcza że zarówno władze okupacyjne, jak rząd Vichy wzywały do takich zachowań i często posługiwały się listami gończymi, przede wszystkim gdy poszukiwały sprawców zamachów na żołnierzy niemieckich.

Po zamachu na komendanta polowego w Nantes i pierwszych poważnych represjach niemieckich (rozstrzelaniu w październiku 1941 r. pięćdziesięciu zakładników) marszałek Pétain w patetycznej odezwie do ludności nakłaniał do denuncjacji: „Powstańcie przeciwko temu spiskowi. Pomóżcie wymierzyć sprawiedliwość [...]. Apeluję o to do was łamiącym się głosem. Nie pozwólcie już, by wyrządzano krzywdę Francji”. Ze swej strony wiceprezes Rady François Darlan wygłosił oficjalne przemówienie, w którym kusił potencjalnych donosicieli obietnicą korzyści osobistych: „Wasze dobro, dobro naszych uwięzionych, których pragniemy jak najszybciej znowu tu ujrzeć, nakładają na was obowiązek przekazywania nam wszelkich informacji, jakie do was docierają, a dotyczą przygotowania aktów agresji. Dlatego też waszym obowiązkiem jest pomaganie nam w chwytaniu tych, którzy je przygotowują lub ich dokonują. Francuzi, w imieniu Marszałka odwołuję się do waszej lojalności, zdrowego rozsądku, do waszego patriotyzmu"28. Na tej fali wprowadzono Ustawę o obowiązku donoszenia o niektórych czynach niezgodnych z prawem lub planowaniu takich czynów i udzielania pomocy osobom w niebezpieczeństwie. Rząd francuski przyjął ją 26 października 1941 r. Dziennik „Le Phare de la Loire” pochwalał takie posunięcia: „Prawo karne przyjęło zasady nowego reżimu, które wymagają oddania, a nawet poświęcenia jednostki dla dobra społeczności”29. Tymczasem prawnik, dziekan wydziału prawa w Tuluzie, stwierdził trzeźwo w komentarzu do ustawy, że przemienia ona „obowiązek obywatelski” „nieutrudniania

reżimu za zdradę. Za czasów sędziego Rolanda Freislera (1942-1945) tysiące ludzi skazano na ścięcie. Lekarz, na którego doniosła pacjentka, przypłacił życiem powątpiewanie w triumf Niemiec w roku 1943.

${ }^{27}$ AN, AJ 38, 1154, Raporty SEC 4, 6 i 7 III 1944 r. (aresztowanie Sury Cyrklewicz, Fajgli Sztybel, Germaine Ryzy, Simona Barancica).

${ }^{28}$ Odezwa marszatka Petaina, Odezwa admirała Darlana, „Le Figaro”, 23 X 1941.

${ }^{29}$ Jean-Marc Berliere, Franck Liaigre, Le Sang des communistes. Les Bataillons de la jeunesse dans la lutte armée. Automne 1941, Paris: Fayard, 2004, s. 334. 
działań wymiaru sprawiedliwości” i „przyczyniania się czynną współpracą do wykrycia winnych, w razie potrzeby przez denuncjację”, w „obowiązek prawny”30.

W tej sytuacji władza dopuściła się przekupstwa - w związku z wydarzeniami w Nantes miasto i prefektura zaoferowały odpowiednio 200 tys. i 500 tys. franków każdemu, kto przekaże informację mogącą pomóc w aresztowaniu zabójców komendanta polowego, a władze okupacyjne wyznaczyły nagrodę w wysokości 15 mln franków $w^{31}$ ! Przez całą wojnę kolaborujące $z$ okupantem organy prasowe i radio raz po raz ponawiały apele: „I wy, drodzy czytelnicy, nie wahajcie się, denuncjujcie, nie miejcie skrupułów, bo to obowiązek każdego Francuza”. To wezwanie wyszło spod pióra publicysty faszystowskiego tygodnika „Je suis partout” (Jestem wszędzie) $^{32}$. W prasie drukowano apele - mniej lub bardziej oficjalne, mniej lub bardziej nachalne, zastraszające najbardziej praworządnych obywateli. Na początku roku 1943 Komisariat Generalny Spraw Żydowskich wydał komunikat dotyczący deklarowania majątku żydowskiego: „Ponieważ niektóre z tych dóbr nie zostały do dziś zgłoszone, urzędnicy ministerialni, administratorzy, pełnomocnicy, zarządcy, dozorcy i lokatorzy, którzy nie wiedzą o wyznaczeniu tymczasowego zarządcy lub zarządcy komisarycznego, mają zgłosić to w ciągu tygodnia na piśmie, wysyłając je do Komisariatu Spraw Żydowskich, plac des Petits-Pères, Paryż”33. Część dozorców uważała za swój obowiązek informowanie CGQJ o Żydach mieszkających „z naruszeniem prawa” w kamienicach: „Mając tu Żydów, którzy w październiku wyjechali do strefy wolnej, jako dozorca informóję [sic!], że ludzie ci całkowicie opróżniają swoje mieszkanie. Jeszcze dziś przysyłają tu chandlarzy [sic!], którzy wynoszą to, co pozostało, pod pretekstem, że komorne jest opłacane. Co powinienem zrobić? Powiadomiłem zarządcę, ale nie chcę mieć problemów, więc wolałem zwrócić się do was. Ci ludzie, polscy Żydzi, to pan Isaac Boutman z żoną, przebywający obecnie w Tuluzie, u Benzackriego, przy ulicy St Jérôme 5”34.

\section{Specyfika donosów antysemickich}

Nienawiść do Żydów odegrała bardzo istotną rolę w historii denuncjacji na ziemiach okupowanych. Jeżeli jednak ufać dokumentom Prefektury Policji w Paryżu,

${ }^{30}$ Joseph Magnol, Loi du 25 octobre 1941 modifiant les articles 228 et 248 du code pénal et portant obligation de dénoncer certaines infractions ou projets d'infractions et de secourir les personnes en danger [Ustawa z 25 X 1941 r. zmieniająca artykuły 228 i 248 Kodeksu karnego i nakładająca obowiązek denuncjonowania niektórych przestępstw lub zamiaru ich popełnienia i udzielania pomocy osobom w niebezpieczeństwie], „La semaine juridique, Doctrine”, nr 241, 1942. Cyt. za Virginie Sansico, „La Répression politique devant les tribunaux de l’État français. Lyon, 1940-1944”, rozprawa doktorska z historii, Université Lyon 2, Lyon 2008, s. 213.

${ }^{31}$ Berliere, Liaigre, Le Sang des commusistes..., s. 133-135, 334.

${ }^{32}$ Cyt. za: Suzanne Benoist, Je suis partout à la barre, „Le Populaire”, 21 XI 1946.

${ }^{33}$ AN, AJ 38, 593. „Należy informować o niezadeklarowanych majątkach żydowskich” - brzmiał komunikat w prasie z lutego $1943 \mathrm{r}$.

${ }^{34}$ AN, AJ 38, 160, Akta Boutmana, List pani H. z 2 III 1943 r. 
6 procent anonimowych listów trafiających do Policji Śledczej mówiło o Żydach ${ }^{35}$. W całym tym okresie odsetek donosów antysemickich był z pewnością wyższy, prawdopodobnie jednak nie osiągnął poziomu ustalonego przez Barbarę Engelking dla Polski lat 1940-1941, gdzie 30 procent listów z donosami przeanalizowanych przez autorkę dotyczyło Żydów ${ }^{36}$. We Francji tych mrocznych lat większość donosicieli wydawała „komunistów” albo ludzi, którzy popełniali przestępstwa gospodarcze lub pospolite.

Oprócz czynników związanych z okupacją (frustracja, podgrzanie nastrojów, możliwość manipulowania rozmówcami itp.) donosy o charakterze antysemickim wpisują się w długą tradycję polityczną̧ ${ }^{37}$ W roku 1886 Édouard Drumont pisał o przejmowaniu Francji przez Żydów w opracowaniu pod tytułem La France juive (Żydowska Francja). Wykorzystując sukces, jaki odniosła ta książka, stworzył cały system literacki i dziennikarski bazujący na donosach. Jego liczne książki i dziennik „La Libre Parole” (Wolne Słowo, wydawane od 1892 r.) opierały się na rozmaitych „rewelacjach”, nadsyłanych przez wielbicieli i sympatyków Drumonta: wiejskich proboszczów, którzy ujawniali „żydowskie przyjaźnie” biskupa, komiwojażerów, którzy krytykowali „manipulacje” żydowskich kolegów po fachu, donosząc na bankierów albo prefektów faworyzujących Żydów itd. Większość tych doniesień zamieszczano na trzeciej stronie dziennika, w rubryce „Trybuna «Wolnego Słowa»”. „Dlaczego Potain wybrał na kierownika laboratorium Springera (Maurice’a)? Springer oszukiwał podczas konkursu na naczelnika lekarzy" - pisał zachowujący anonimowość lekarz antysemita ${ }^{38}$.

Żydowska prasa potępiała „codzienne eksplozje oszczerstw i pomówień, które stały się manną antysemickich gazet” ${ }^{39}$. „La Libre Parole” nazywano „Ojcem Duchesne antysemityzmu”, a rubryka „Trybuna «Wolnego Słowa»” została zamknięta po przegranym przez gazetę procesie o zniesławienie, niemniej tradycja „fiszek”, „liścików" i donosów przetrwała. U schyłku XIX w. pewien komiwojażer opublikował dziesięć broszur, w tym Indicateur des Juifs. Les Juifs dans toute la presse française,

${ }^{35}$ Obliczenia na podstawie: Archiwum Prefektury Policji w Paryżu, PJ 37, Anonimy. Donosy, Zbiór 100 listów. Zwróćmy uwagę, że donos mógł nie dotyczyć Żyda, ale osoby pomagającej Żydowi.

${ }^{36}$ Barbara Engelking, „Cher Monsieur Gestapo...”. La délation aux autorités allemandes en Pologne dans les années 1940-1941, tłum. Agnès Nowicki [w:] Juifs et Polonais 1939-2008, red. Jean-Charles Szurek, Annette Wieviorka, Paris: Albin Michel, 2009, s. 45-59 [por. wyd. oryg. "Szanowny panie gistapo”. Donosy do wtadz niemieckich $w$ Warszawie i okolicach w latach 1940-1941, Warszawa: Wydawnictwo IFiS, 2003, s. 73-81 - przyp. red.].

37 Oczywiście, przed rokiem 1940 policja wykorzystywała anonimy antysemickie, na przykład departament Ministerstwa Spraw Wewnętrznych przekazał w maju 1939 r. innemu departamentowi anonimowy donos informujący o fałszowaniu na dużą skalę wiz dla żydowskich emigrantów. AN, F 7, 16080, nota dla Mondatela, inspektora generalnego Policji Kryminalnej w sprawie „Palestyna i Orient Floyd”, podpisana przez Amédée Bussière’a, 2 V $1939 \mathrm{r}$.

38 „Tribune de «La Libre Parole»”, „La Libre Parole”, 11 V 1892.

39 „Archives israélites”, 3 I 1895. 
l'armée et la finance parisienne (Tropiciel Żydów. Żydzi we francuskiej prasie, armii i paryskiej finansjerze) ${ }^{40}$. W latach 1908-1914 rubryki „Echa” i „Kalendarz afery Dreyfusa” w rojalistycznym dzienniku skrajnej prawicy „L'Action Française” (Akcja Francuska) roiły się od niemal jawnych gróźb pod adresem Alfreda Dreyfusa, którego w sposób dosłowny tropiono, pisząc dzień w dzień, gdzie przebywa. Właśnie ten styl odnajdujemy w paryskich gazetach lat 1940-1944. „Au Pilori” (Pod Pręgierzem) w swoich tematycznych rubrykach podjęło dzieło „La Libre Parole”, szczególnie pod redakcją starego Jeana Draulta (1943-1944), który już wcześniej był podporą redakcji dziennika Drumonta.

Według antysemitów każde stanowisko zajmowane przez Żyda w strukturach państwowych, handlu czy wolnym zawodzie, zwłaszcza wysokie, może być tylko owocem knowań. Dlatego pisano o tym w prasie, podkreślano, potępiano albo po prostu grożono. Począwszy od roku 1940, wszelkie wyobrażalne wady przypisywane Żydom również skłaniały do denuncjacji każdego „wykroczenia”. Siła tej tradycji wyjaśnia, dlaczego za czasów okupacji tak wiele instancji pośredniczyło między donoszącym obywatelem a władzami, co dotyczyło wyłącznie spraw żydowskich. Dziennik „Au Pilori” i inne podobne jawnie denuncjowały na swoich łamach Żydów, którzy nie zgłosili, że nadal pracują lub wykonują któryś z zakazanych zawodów. W ten sposób gazety prowokowały do wszczynania śledztw i do aresztowań ${ }^{41}$. Instytut Badań Kwestii Żydowskiej specjalizował się w takich sprawach i na bieżąco przekazywał do Komisariatu Generalnego Spraw Żydowskich informacje uzyskiwane od pracowników i sympatyków. Biuro łączności ze słuchaczami programu „Róża Wiatrów"42, emitowanego na falach Radia Paryż, przekazywało listy z donosami do CGQJ. W maju 1943 r. dyrektor gabinetu Komisariatu Joseph Antignac mówił: „cieszę się, widząc wasze oddanie naszej wspólnej sprawie, szczególnie zaś dziękuję za dobrowolną i stałą współpracę" ${ }^{\prime 3}$.

Także inne instytucje uznawały za swój obowiązek powiadamianie władz o „żydowskich manewrach”, na przykład Komitet Obrony przed Komunistami, który zadenuncjował w lipcu 1942 r. rosyjskiego Żyda, zatrudnionego jako tłumacz z niemieckiego przez merostwo La Mothe-St-Heray, które to „wciąż ma powiązania z Frontem Ludowym”: „Wszyscy dobrzy Francuzi są oburzeni”. CGQJ doprowadziło do internowania tego Żyda w obozie w Poitiers i przekazało Komitetowi podziękowania: „Informacje, które od was otrzymałem, umożliwiły uwolnienie mieszkańców La Mothe od niepożądanego intruza, za co bardzo dziękuję"44. Komisariat mógł także liczyć na siatkę sympatyków, zawsze gotowych wspierać

${ }^{40}$ Béatrice Philippe, „L'identité épinglée”. L'Indicateur israélite de Philippe Sapin (1896). Un ouvrage antisémite au temps de l'Affaire, „Yod” 1987, nr 24, s. 91-113.

${ }^{41}$ Por. donos Cécile Lehwess, który doprowadził do podjęcia przez SEC śledztwa (AN, AJ 38, 177, Akta Lehwess, Raport SEC, 9 III 1943 r.).

${ }^{42}$ Por. AN, Z 6, 117, 1707, Robert Peyronnet.

${ }^{43}$ AN, AJ 38, 159, Akta Blum, List Antignaca do „Róży Wiatrów”, 24 V 1943 r.

${ }^{44}$ AN, AJ 38, 176, Akta Kutener, List przewodniczącego Komitetu Obrony przed komunistami i Żydami do CGQJ, 30 VII 1942 r.; ibidem, Odpowiedź z 15 X 1942 r. 
poczynania, którym przyświecała idea czystości narodowej. W Sospel Robert D., działacz Parti populaire français (PPF - Francuska Partia Ludowa) Jacques'a Doriota, zwrócił się przeciwko niejakiemu Dreyfusowi, który jako wolontariusz pracował w merostwie i prowadził działalność publiczną: „Większość mieszkańców SOSPEL słusznie uważa za skandaliczne, że po wprowadzeniu wszystkich przepisów ograniczających prawa Żydów osobnik tej rasy znalazł miejsce w służbie publicznej”45. Dreyfusa postawiono przed sądem karnym w Nicei, ale ku wielkiemu rozczarowaniu donosiciela sprawę umorzono (nawiasem mówiąc, noszący nazwisko Dreyfus człowiek nie był zgodnie z obowiązującym prawem Żydem). Również niejaki Jacques Roze, były sekretarz osobisty Louisa Darquiera de Pellepointa (1935-1939), aktywista Grupy Współpracy, odwiedził posterunek policji w swej dzielnicy w Paryżu, żeby donieść, że jego młoda sąsiadka nie nosi gwiazdy Dawida. „Składając doniesienie, zaznaczył, że «nie należy folgować takim ludziom, bo jeśli damy im okazję, oni nie będą mieć dla nas litości»” - opowiadał po wyzwoleniu policjant, który przyjął zgłoszenie ${ }^{46}$.

Donosy na Żydów brały się przede wszystkim ze zwykłej nienawiści, która czasami wynikała z zazdrości o sukces zawodowy albo finansowy, najczęściej jednak żywiła się sama sobą: „Szanowny Panie, nienawidzę Żydów, którzy wyrządzili nam tyle zła, i dlatego cieszę się, mogąc donieść na jednego z nich i zdemaskować jego sztuczki, kiedy próbuje obejść przepisy wprowadzone po to, żeby Żydzi nie mogli już nam szkodzić”47. „Szanowny Panie, pałam nienawiścią do Żydów, uważam więc, że moim obowiązkiem jest zgłosić, iż pewna osoba żydowskiego pochodzenia, cudzoziemka, która przebywa tu nielegalnie, porusza się i podróżuje, a poza tym, co oczywiste, nie nosi znaku gwiazdy"48.

Nawet jeśli główną pobudką działania jest chciwość albo sąsiedzkie waśnie, akt donosicielstwa ma zawsze tło ideologiczne. Na przykład w jakiś czas po obławie na rumuńskich Żydów w Paryżu (wrzesień 1942 r.) Maurice L., opryskliwy monter, którego żona chorowała już od lat, wydał sąsiadów ocalałych po tej opresji - dwudziestoletnią dziewczynę, pięciomiesięczne niemowlę i sześćdziesięcioletnią babkę. Sąsiedzi byli hałaśliwi i od końca lat trzydziestych L. stale się z nimi kłócił. W listopadzie 1942 r. napisał do dowódcy wojsk niemieckich we Francji:

Ekscelencjo, przepraszam, że zwracam się wprost do Pana, chciałbym jednak poinformować, że od pewnego czasu aktywność niektórych Izraelitów stała się dużo bardziej aktywna [sic!]. Nade mną, odkąd przyszli po osoby zamieszkujące ten lokal, przyjścia i wyjścia przyjaciół tych Żydów stały się, oględnie mówiąc, niezwykle częste. To nieustanny przemarsz, nie ma więc cienia wątpliwości, że musi mieć związek z obecnymi wydarzeniami i całym tym zamętem.

\footnotetext{
${ }^{45}$ AN, Z 6, 252, Akta nr 2967, List do CGQJ w Nicei, 5 XII 1941 r.

${ }^{46}$ AN, Z 6, 404, Akta nr 4141, Charles Roze, Zeznania Léonce B., 14 II 1947 r.

${ }^{47}$ AN, AJ 38, 160, Akta Ziny B., Anonim, 20 X 1943 r. Śledztwo doprowadziło do aresztowania pani B., która nie została deportowana.

${ }^{48}$ AN, AJ 38, 180, Akta Esther M., Anonim przysłany 28 X 1943 r.
} 
Po tej niezręcznej opowiastce, w której usiłował przedstawić sąsiadów jako groźnych wrogów politycznych, L. zaczął się rozwodzić nad własnymi nieszczęściami, wspomniał o chorej żonie, która potrzebuje spokoju, użalał się, że ci Żydzi nie zostali wywiezieni jak inni: ta babka, „nie była w stanie wyjechać, bo ponoć miała jakieś boleści czy reumatyzm. Ale to wcale jej nie przeszkadza wychodzić z domu, i to nawet bez żydowskiej odznaki”49. Rok później, po kolejnych brutalnych awanturach i jawnych groźbach: „ty dwudziestoletnia gówniaro, wyślę cię tam, gdzie są twoi rodzice”, „wypruję ci flaki”, „dziwko, pójdziesz do swoich rodziców”50, Maurice L. doprowadził w końcu, pisząc donos do gestapo, do aresztowania i deportacji dziewczyny, Liliane Calman, która nie wróciła z Auschwitz...

Jasne jest, że nikt nie denuncjował Żydów CGQJ, policji czy władzom niemieckim, nie zdając sobie sprawy z konsekwencji i nie kierując się choć po części antysemityzmem. Pod tym względem najbardziej zdumiewające są donosy Żydów na innych Żydów. Mąż dentystki, która „już dalej nie mogła”, pisał do Xaviera Vallata w maju 1941 r.: „Podziwiam tę sprawiedliwość i popieram was, choć jestem Żydem, potomkiem rodziny, której tradycja sięga wypraw krzyżowych, i mimo że mój brat poległ na tej wojnie, a dwaj inni są w niewoli”. Otóż dentystka nazwiskiem Dreyfus zmieniła tabliczkę i praktykowała pod nazwiskiem matki nie-Żydówki: „Moim zdaniem obie córki mają domieszkę żydowskiej krwi po ojcu, a wiele zapłacili, żeby to osiągnąć. To niesprawiedliwe!” - oburzał się ten „dobry francuski Żyd”51.

\section{CGQJ wobec denuncjacji i donosicieli}

Komisariat Generalny Spraw Żydowskich to prawdopodobnie instytucja, która za czasów okupacji otrzymała najwięcej donosów antysemickich, wysyłanych bezpośrednio przez obywateli albo przekazywanych przez inne struktury lub wspomniane już organizacje, które pośredniczyły w tym procederze.

Początkowo służby Xaviera Vallata starały się wprowadzić pewne zasady wykorzystania tego typu informacji. W roku 1941 CGQJ nie uwzględniał listów bez podpisu ${ }^{52}$, potem jednak imperatywy polityki antyżydowskiej wzięły górę nad wątpliwościami natury moralnej. Dyrekcja w Vichy przekazała delegaturze w Marsylii anonimowy list demaskujący żydowskiego adwokata: „Choć w zasadzie do anoni-

\footnotetext{
${ }^{49}$ AN, Z 6, 85, Akta nr 1309, Maurice L., List z 14 X 1942 r.

${ }^{50}$ Ibidem, Raporty policyjne z 1 IX 1944 r., 15 II i 26 V 1945 r., zeznania sąsiadów.

${ }^{51}$ Sprawę przekazano do Wydziału do spraw żydowskich w Prefekturze Policji (6 Biuro-J). Odette Dreyfus, dentystka, była pół-Żydówką wyznania katolickiego. Zgodnie z obowiązującym prawem nie była więc Żydówką. AN, AJ 38, 165, Akta Ernestine Dreyfus, Anonimowy donos wysłany do CGQJ, czerwiec $1941 \mathrm{r}$.

${ }^{52}$ Nawet podpisane listy traktowano początkowo ostrożnie. Na przykład list z 20 VIII 1941 r.: „Informuję (zarówno w interesie społeczności francuskiej, jak i ze względu na to, co uważam za zwykły akt sprawiedliwości wobec mnie) o obywatelu Węgier, Zoltanie Liebermannie”. List jest podpisany, a na marginesie widnieje ogromny wykrzyknik i uwaga: „Donos do archiwizacji”. AN, AJ 38, 179.
} 
mowych listów nie należy nadawać większego znaczenia, proszę tym razem w drodze wyjątku przeprowadzić postępowanie i informować mnie o wszystkim"53.

Policja do spraw żydowskich (Police aux questions juives, PQJ), powołana w październiku 1941 r., a mająca wspierać działania CGQJ (po roku zastapiona przez SEC), wprowadziła równie rygorystyczne zasady. Prawnik kierujący służbami w Vichy, François Luciani, poprosił kolegów z CGQJ o przechowywanie kopert, w których przysyłano donosy - podpisane i anonimowe: „Proszę, by zlecając nam podjęcie śledztwa w sprawie listu, przesyłać mi jego kopię, a także oryginał koperty. Dzięki temu stosunkowo łatwo będzie odnaleźć autora listu, jeżeli śledztwo wykaże, że donos jest oszczerstwem lub został napisany z zamiarem wprowadzenia w błąd naszych służb"54.

Wkrótce donosy okazały się nieodzownym elementem polityki antyżydowskiej. Wykrywanie handlu, spółek i przedsiębiorstw pod „wpływem żydowskim” było możliwe na taką skalę ze względu - jak to nazywano - na „informacje” przekazywane przez obywateli. „Szanowna Pani, interesuje nas dokładny adres tych żydowskich sklepów przy Passage-Branly, a także nazwiska Żydów, którzy czerpią z nich zyski. Może pani liczyć na pełną dyskrecję Komisariatu w sprawie pani danych” - odpowiedział jesienią $1941 \mathrm{r}$. sekretariat CGQJ donosicielce ${ }^{55}$.

W Paryżu Komisariat zatrudniał redaktora, którego zadaniem było przekazywanie tego typu korespondencji poszczególnym wydziałom. Przez dwa lata tę niewdzięczną funkcję pełnił Jean Bouvyer ${ }^{56}$. Średnio jeden list dziennie trafiał za jego sprawą do PQJ, a następnie do SEC ${ }^{57}$. Za czasów Josepha Antignaca, który kierował CGQJ od roku 1943, listowne donosy były wykorzystywane na szeroką skalę.

Dzięki katalogom Centrum Współczesnej Dokumentacji Żydowskiej mogliśmy poznać treść około stu donosów przysłanych do Komisariatu od 1941 do 1944 r. W zbiorze tym można wyodrębnić cztery kategorie donosów. Do pierwszej należą rozmaite oskarżenia, często bez żadnych skutków (dotyczące Żydów, którzy uciekli do strefy wolnej lub mieli działać na czarnym rynku itp.) Na przykład pani J., „ofiara żydowskiej nienawiści”, napisała do Xaviera Vallata, aby przedstawić mu swój konflikt z żydowskim lokatorem, który „uchylał się od opłat”58. Od czasu do czasu Komisariat przekazywał niektóre listy paryskiej prefekturze (Żyd cudzoziemiec zamieszany w nielegalny handel itp.). Zebrałem 49 takich listów. Druga kategoria, do

${ }^{53}$ AN, AJ 38, 136, List do regionalnej dyrekcji CGQJ w Marsylii z 27 IX $1941 \mathrm{r}$.

${ }^{54}$ CDJC, CCXXXVIII-17, List szefa PQJ (autorstwa Lucianiego) do CGQJ w Vichy, 19 II $1942 \mathrm{r}$.

${ }^{55}$ AN, AJ 38, 181, List sekretariatu CGQJ, 7 X 1941 r.

${ }^{56}$ Był w młodości przyjacielem François Mitterranda. Por. Pierre Péan, Une jeunesse françoise. François Mitterrand, 1934-1947, Paris: Hachette, 1995.

${ }^{57}$ Por. AN, Z 6, 1387, teczka 55 - około 45 w czerwcu i lipcu 1942 r.; teczka 53 - 30 listów przekazanych przez CGQJ do PQJ/SEC w Paryżu w sierpniu i wrześniu 1942 r.; teczka 52 - 10 listów przekazanych z CGQJ do SEC w dniach 15-30 IX 1942 r; teczka 51 - 12 listów przekazanych we wrześniu i teczka 54 - 30 z października 1942 r.

${ }^{58}$ CDJC, CCXXXIX-18, List pani J. do Vallata, 21 VI $1941 \mathrm{r}$. 
której zaliczyłem 29 ze znanych mi listów, dotyczy polityki zagarniania majątków żydowskich - pewien rolnik pisał o „żydowskiej” posiadłości ziemskiej, tymczasowy zarządca, przekonany, że wykrył sklep należący do Żyda, zgłosił ten fakt. Trzecia kategoria (18 listów) odnosi się do wykonywania zawodów zabronionych (jedną trzecią donosicieli stanowią tu lekarze, oskarżający kolegów po fachu). I wreszcie ostatnia grupa to listy od osób, które informują o nienoszeniu żółtej gwiazdy Dawida przez Żydów w strefie okupowanej, o ukrywających się itd., a zatem skazują ich na niemal pewne aresztowanie przez policję niemiecką lub francuską. Zebrałem 10 takich listów.

Spośród 106 donosów 31 to anonimy, a 75 opatrzono podpisami. Choć liczby należy traktować ostrożnie - donosiciele podpisywali się zmyślonym nazwiskiem, aby uwiarygodnić zarzuty, ale nie ujawniać tożsamości, jak pewien „Jean Richard”, który kilkakrotnie zwracał się do CGQJ, by donieść o fikcyjnej aryzacji firmy ${ }^{59}$ - możemy stwierdzić, że większość donosicieli nie zamierzała się ukrywać. Dzieje się tak zwłaszcza w wypadku osób, które pisały o sprawach gospodarczych (tu zaledwie 4 anonimy na 29 donosów) oraz o Żydach wykonujących zakazane zawody (3 listy anonimowe na 18). Autorzy najohydniejszych albo najbardziej absurdalnych donosów ukrywali się częściej (19 anonimów na 49 listów w pierwszej kategorii, 5 na 10 w ostatniej). Należy dodać, że dość często donosiciel poruszał sprawę, która interesowała go osobiście, toteż musiał działać jawnie. Pewna pani z kręgów burżuazyjnych zwierzyła się Komisariatowi Generalnemu Spraw Żydowskich ze swoich problemów małżeńskich: „Zwracam się z prośbą o pomoc i ochronę przed Żydówką, która ugania się za moim mężem, używając przebiegłości typowej dla swej rasy i z typową bezwstydnością"60.

Jeśli chodzi o płeć donosicieli, to widać wyraźną dominację mężczyzn, co przeczy powszechnym wyobrażeniom ${ }^{61}$. Uwzględniając 7 listów anonimowych, w których ujawniono płeć autorów („legionista”, „Francuzka”, „antysemita” itd.), można stwierdzić, że z 82 listów podpisanych z analizowanej próbki, 65 wysłali mężczyźni, a 17 kobiety ${ }^{62}$. Również wbrew schematom, donosy z powodu rozczarowań miłosnych nie były domeną kobiet. Pan Dupont, rozwodząc się, doniósł na kochanka żony - węgierskiego Żyda ${ }^{63}$.

${ }^{59}$ Ibidem, XXXIX-145, List tymczasowego zarządcy do CGQJ, 7 X $1942 \mathrm{r}$.

${ }^{60}$ AN, AJ 38, 154, List pani A. do CGQJ, 6 IX 1942 r.

${ }^{61}$ Gellately, Avec Hitler... Autor także podkreśla znaczny odsetek mężczyzn.

${ }^{62}$ Taki sam wniosek wyciąga Patrice Betbeder, Dénoncer à Paris durant la Seconde Guerre mondiale [w:] Citoyens et délateurs. La délation peut-elle être civique?, red. Jean-Paul Brodeur, Fabien Jobard, Paris: Autrement, 2005, s. 72. Twierdzi on, że wśród donosicieli było 30 procent kobiet (Archiwum Prefektury Policji w Paryżu). Natomiast analiza 225 donosów z archiwów departamentu l'Eure pozwoliła Julienowi Pappowi ustalić, że kobiety stanowiły 65,5 procent donosicieli (Julien Papp, La Collaboration dans l’Eure 1940-1944, Paris: Tirésias, 1993, s. 181-182).

${ }^{63}$ CDJC, XXXVIII-17a, trzy listy do Vallata, 23 IX 1941-17 II 1942 r. 
I wreszcie wśród 106 znalazły się 2 listy wysłane przez Żydów. Niejaki pan Lévy, wcześniej internowany w obozie w Drancy, zadenuncjował mieszkającą w jego kamienicy rodzinę, która żyła $\mathrm{z}$ handlu na czarnym rynku, narażając $\mathrm{w}$ ten sposób sąsiadów na aresztowanie „Źli Żydzi” szkodzą „dobrym Żydom” - wyjaśnił ${ }^{64}$.

Trudno oszacować, ile donosów trafiło łącznie do CGQJ. Na podstawie rejestrów Wydziału Korespondencji ${ }^{65}$ można stwierdzić, że kilka anonimów - zwykle 2-3, a po obławach z 16 i 17 lipca 1942 r. 7-8 - docierało co dzień na plac Petits-Pères 1 w Paryżu. Szacuje się, że donosów tego typu wysłanych do Komisariatu Generalnego od wiosny 1941 do lata 1944 r. było około 5000, jeśli przyjąć, że tygodniowo do wszystkich wydziałów CGQJ docierało około 30 anonimów (do centrali i wydziałów regionalnych). Na próbce 106 listów ustaliłem, że ponad połowa donosów była podpisana, z czego wniosek, że za czasów okupacji CGQJ otrzymał ich 10 000-20 000. To zaniżone szacunki. Wiele donosów kierowano przy okazji, w korespondencji adresowanej do dowódców Komisariatu. Listy otrzymane przez Darquiera de Pellepointa od chwili jego nominacji można podzielić na trzy grupy: gratulacje, deklaracja antyżydowskiego nastawienia, drobne donosy...

Z przeanalizowanych listów wyraźnie wyłaniają się dwa typy korespondentów. Pierwszy to antysemici wojujący i „wykształceni”, piszący wprost do Vallata lub Darquiera. Są pewni siebie, w listach już na początku podkreślają wspólnotę, harmonię idei. Wiedzą, że Komisariat potrzebuje ich informacji i z własnej woli podejmują współpracę. Inaczej rysuje się portret sfrustrowanego donosiciela, który często się nie podpisuje, nie zna systemu prześladowań, a pisze do CGQJ, jakby pisał (albo pisze także) do prefektury policji czy gestapo. Zdaje się na los, mając nadzieję, że jego denuncjacja poskutkuje.

„Wpływ” Żydów uważany był za „szkodliwy” od tak dawna, że wszelkie metody ich zwalczania wydawały się usprawiedliwione. „Przykro nam, że musimy przekazywać informacje od tak mało ważnych korespondentów, czyż jednak nie należy walczyć wszelkimi możliwymi metodami z tą znienawidzoną rasą?” - usprawiedliwiał się Jean-Claude Maubourguet, dziennikarz „Je suis partout”, przesyłając do CGQJ serię anonimów ${ }^{66}$. „Ponieważ donosicielstwo nie leży w mojej naturze, wahałem się, czy przekazać panu ten przypadek, pamiętam jednak, co Pan nam mówił na rue Laugier”67, tłumaczył dawny działacz Zgromadzenia Antyżydowskiego w liście do Louisa Darquiera de Pellepoix ${ }^{68}$.

${ }^{64}$ CDJC, XXXVIII-99, List Lévy'ego do CGQJ, 14 VII 1943 r.

${ }^{65}$ AN, Z 6, 1377-1379, Rejestr korespondencji odebranej od 12 I 1942 do 30 VIII 1944 r.

${ }^{66}$ AN, AJ 38, 6, List Maubourgueta do Bouvyera, 23 VI 1942 r., dołączony do donosu czytelnika „Je suis partout”.

${ }^{67} \mathrm{~W}$ kamienicy przy ul. Laugier $12 \mathrm{w}$ Paryżu mieściła się siedziba Zgromadzenia Antyżydowskiego Darquiera.

${ }^{68}$ Ten donos doprowadził do aresztowania O. Hircha [Hirscha?]: „Chodzi o niejakiego Hircha O., Bulwar de la République w St. Cloud. Ten typ był członkiem Aeroklubu Francuskiego i niegdyś miewałem z nim ostre utarczki. Spotkałem tego grubasa, wciąż tak tłustego i różowego, bez gwiazdy, w kawiarni. Kiedy mnie zobaczył, wyglądał, jakby chciał mnie 
Inni nie przeżywali podobnych rozterek. Według Philippe’a Henriota, który we wrześniu 1942 r. przesłał trzy listy, było to zupełnie normalne postępowanie ${ }^{69}$. Również pewien dyplomata najzwyczajniej wysłał kartkę do przyjaciela, Gastona Riou, deputowanego z Ardèche, znanego głosiciela idei europejskiej w latach międzywojennych ${ }^{70}$, dorzucając: „a skoro jesteś blisko pana Xav. Vallata” [czyli: skoro Riou jest w Paryżu i zna Vallata, także deputowanego z Ardèche], i denuncjuje Żyda-bibliotekarza: „Dowiedziałem się, że Chapiro nadal bezkarnie łamie prawo, już dziesiąty rok wzbudzając oburzenie. Czy mógłbyś wysłać tego niebezpiecznego złoczyńcę, tego Żyda, do obozu? Jest Polakiem. Przysłużyłbyś się i Akademii, i ojczyźnie. Serdeczności od nas dwojga dla was dwojga"71.

Na pozór jest to najzwyklejsza karta pocztowa z pozdrowieniami od małżeństwa F. dla małżeństwa Riou, a małżonki obu panów stają się współodpowiedzialne za donos, który każdy może przeczytać (kartka pocztowa ze znaczkiem za 800 centymów, tym z marszałkiem Pétainem). I równie zwyczajnie Gaston Riou przekazał tę kartkę ( $\mathrm{z}$ adresem ofiary), do Komisariatu Generalnego ${ }^{72}$.

\section{„Informacje” SEC}

Większość denuncjacji wysłanych do CGQJ nie pociągała za sobą, jak się wydaje, żadnych konsekwencji, ale jakaś ich część odegrała ogromną rolę w polityce prześladowań - liczne majątki żydowskie zostały oddane w tymczasowy zarząd i zagarnięte w wyniku „informacji”; poza tym SEC bazowała w ogromnej mierze na donosach. Znacznie przekraczając swoje uprawnienia, departament policyjny Komisariatu zatrzymał na ulicach Paryża 850 do 900 osób, spośród których 650 deportowano za naruszenie niemieckiego prawa (nienoszenie gwiazdy Dawida, bywanie w miejscach publicznych itd.) ${ }^{73}$. Przejmując jesienią 1942 roku funkcje Policji do spraw żydowskich, SEC nie dysponowała tradycyjnymi narzędziami śledczymi, dlatego musiała opierać się na „informacjach” pozyskiwanych od obywateli. Na południu siatka płatnych donosicieli zaczęła funkcjonować już w roku $1942^{74}$. W przededniu wyzwolenia w Paryżu jeden z ostatnich szefów SEC, André Haffner,

dopaść. Nie można by go «ugwieździć [étoiler]?»” AN, Z, 6, 1387, teczka 41, List R.A., pisarza sądowego, do Darquiera de Pellepoix, 21 X 1942 r. Po śledztwie SEC Hirsch został zatrzymany, internowany w Drancy, ale chyba uniknął deportacji.

${ }^{69}$ AN, AJ 38, 19, List Henriota do Darquiera, 24 IX 1942 r.

${ }^{70}$ Bernard Bruneteau, „L'Europe nouvelle” de Hitler. Une illusion des intellectuels de la France de Vichy, Monaco: Éditions du Rocher, 2003, s. 221-235.

${ }^{71}$ AN, AJ 38, 168, Akta F., Pocztówka F. do Riou, 1 IX 1941 r.

${ }^{72}$ Znajdującą się $\mathrm{w}$ archiwach CGQJ pocztówkę opatrzono adnotacją: „Przekazana p. Jacques'owi Ditte'owi dnia...” (data nieczytelna).

${ }^{73}$ Laurent Joly, Vichy dans la „solution finale”. Histoire du commissariat général aux Questions juives (1941-1944), Paris: Grasset \& Fasquelle, 2006, s. 623-643.

${ }^{74}$ W sierpniu 1942 r. budżet SEC w strefie wolnej zawierał „fundusz specjalny” na „zaproszenia” i ,informatorów”, wynoszący 10000 franków. AN, AJ 38, 244, List Antignaca do Schweblina, 7 IX $1942 \mathrm{r}$. 
współpracował z grupą płatnych informatorów. Ale właśnie listy z donosami i ustne informacje, niekiedy telefoniczne, od aktywnych antysemitów stanowiły podstawę policyjnej działalności CGQJ. W roku 1944 system funkcjonował już bardzo sprawnie - donosy segregowano według dzielnic, zajmowali się nimi wyznaczeni inspektorzy ${ }^{75}$.

Jeżeli wierzyć raportom inspektorów SEC, co najmniej połowę śledztw prowadzono pod wpływem donosu. Zapewne jednak ich znaczenie było większe, ponieważ specjalizujący się w tropieniu Żydów policjanci mieli skłonność do przeceniania w raportach własnej inicjatywy i wyników śledztw, pozwalało im to bowiem uzasadnić koszty realizacji zadań... Na przykład w raporcie z aresztowania młodego Raymonda Kagana pojawiła się wzmianka o pracy na ulicy: „Na ulicy Alphonse Karr zatrzymaliśmy opuszczającego kamienicę osobnika o żydowskich rysach, który jechał na rowerze o numerze 7566 RN 6 i nie nosił gwiazdy"76. W rzeczywistości chłopak został wydany przez dozorczynię. Inspektor SEC pojawił się na ul. Alphonse Karr w związku ze śledztwem dotyczącym innej osoby podejrzewanej o żydowskie pochodzenie, a dozorczyni powiedziała wówczas: „Widzi pan tego chłopaka na rowerze? To Żyd, ale nigdy nie nosi gwiazdy"77. Inspektor zaczekał z kolegą na powrót Kagana, aby złapać go „na gorącym uczynku”. Raymond miał osiemnaście lat. Zginął w Auschwitz.

Denuncjacje to główne narzędzie pracy SEC. 31 maja 1943 r. CGQJ zarejestrował donos na żydowską prostytutkę, złożony przez jej koleżankę ${ }^{78}$ : „Na ogół nie nosząc gwiazdy, kobieta ta skrycie uprawia prostytucję i stanowi zagrożenie publiczne ze względów sanitarnych, nie poddaje się bowiem badaniom lekarskim"79 24 czerwca kobietę aresztował inspektor Meynadier ${ }^{80}$. Deportowana 18 lipca 1943 r., została zgładzona w Auschwitz. Turecka modelka, która pracowała w firmie Jeanne Lanvin przy bulwarze Saint-Honoré w Paryżu, została wydana w podobny sposób: „Ma stały kontakt z klientelą. Szczyci się swą rasą, lży antysemitów i sieje gaullistowską propagandę. Jej numer domowy to Littré 45.28, ale informacja telefoniczna ma zakaz podawania adresu"81. W czerwcu 1943 r. inspektor Arrighi udał się do Jeanne

${ }^{75}$ AN, Z 6 NL, 6954, Akta ze śledztwa Permilleux, Przesłuchanie Jeana Bonzans’a, 21 IV $1948 \mathrm{r}$.

${ }^{76} \mathrm{AN}, \mathrm{AJ} 38,222$, Raport SEC, $10 \mathrm{~V} 1944 \mathrm{r}$.

${ }^{77}$ AN, Z 6, 10, Akta nr 164, Clémence R., liczne zeznania, w tym sąsiadki, nie-Żydówki, Raymonde L., 12 XII 1944 r. Pani R. została uniewinniona przez sąd w styczniu 1945 r.

${ }^{78}$ Prawo nie zakazywało żydowskim prostytutkom w latach okupacji uprawiania zawodu. Jean-Marc Dreyfus, L'aryanisation économique de maisons de prostitution. Un éclairage sur quelques proxénčtes juifs en France occupée, 1940-1944, „Revue des études juives” 2003, nr 1-2, s. 225-226.

${ }^{79} \mathrm{AN}, \mathrm{Z}$ 6, 1387, teczka 37, Donos zarejestrowany $31 \mathrm{~V} 1943 \mathrm{r}$.

${ }^{80}$ Ibidem, Raport SEC, 24 VI 1943 r. Viviane Chich, urodzona 31 XII 1914 r. w Algierze, przetrwała kilka miesięcy. Jej małżonka deportowano 22 VI 1942 r., pięcioro dzieci udało się ulokować na wsi. Kobieta została w Paryżu, zapewne po to, by wysyłać im pieniądze.

${ }^{81}$ Informacje zdają się pochodzić od tymczasowego zarządcy. Można rozpoznać pismo Antignaca: „Przeprowadzić śledztwo. Informacje dostarczone przez Fontréaulta”. Dokumenty 
Lanvin i zastał tam Bellę Ariel urodzoną w roku 1912 w Konstantynopolu. Kobieta utrzymywała, że pracuje „tylko w studiu, a zatem nie ma kontaktu z klientami”. Ponieważ wynajmowała mieszkanie w pobliżu miejsca pracy, bez pozwolenia, łamała niemieckie rozporządzenia nr 3 i 6, toteż została zabrana na posterunek policji przy Operze $^{82}$. Deportowano ją 18 lipca 1943 r., transportem nr 57. Nie wróciła.

Najbardziej narażeni byli Żydzi, którzy nie nosili gwiazdy Dawida: „Szanowny panie, pragnę zgłosić przypadek Żydów, którzy nie noszą już gwiazdy. Żydówka pracuje u Delangre’a, Fbf St-Denis 202, w głębi pasażu i od kilku miesięcy chodzi bez gwiazdy”. Ten list doprowadził do śledztwa we wskazanym miejscu. Liba Polonski (z domu Kozłowska) zostaje aresztowana ${ }^{83}$ i deportowana 18 lipca 1943 r. Zginęła w Auschwitz.

Gdyby nie zaciekłość sąsiadów lub kolegów z pracy, antysemitów, setki paryskich Żydów zdołałyby uniknąć śmierci. Jak CGQJ odkryłby prawdziwe pochodzenie Agathe Lachassagne, alzackiej Żydówki, która się nie ujawniła, ale została wydana w kwietniu 1943 r. przez sąsiada? „Jej panieńskie nazwisko to Kahn Agathe Alice, córka Kahna i jego żony, z domu Lippmann, urodzona w Brumath w Alzacji w roku 1882 albo 1883. [...] W nadziei, że zechce Pan uwzględnić te informacje i podjąć stosowne działania, pragnę wyrazić me oddanie i szacunek" ${ }^{84}$. Kobietę aresztowali w jej domu inspektorzy Douillet i Delerse i przekazali Wydziałowi do spraw żydowskich gestapo ${ }^{85}$. Deportowano ją 7 października 1943 r. Inspektorzy

przekazano 20 V 1943 r. do SEC. Pierwszy donosiciel w tej sprawie to Marcel de Font-Réaulx, późniejszy prezes Francuskiego Stowarzyszenia Majątków Zaryzowanych. Font-Réaulx był wspólnikiem przyjaciela Belli Ariela w spółce Line Peuch. Dodajmy, że przesłuchiwany w roku 1949 (Font-Réaulx zmarł w 1948 r.), przyjaciel ów wyznał z niedowierzaniem: „Nie sądzę, żeby był donosicielem. Podkreślam, że kiedy [kobieta ta] została internowana w Drancy, prosiłem Font-Réaulxa o interwencję u Antignaca, aby ją uwolnić. Powiedział mi, że nic nie może zrobić”. Centre des archives contemporaines w Fontainebleau (dalej CAC), 890158/13, Przesłuchanie Édouarda M., 18 VI 1949 r. Jest jednak niemal pewne, że Font-Réaulx postąpił odwrotnie, dostarczając Antignacowi plotek i precyzyjnych informacji, które można znaleźć w liście dyrektora sekretariatu CGQJ do gestapo: „Potwierdzam, że informacje, które do mnie dotarły, dowodzą, iż kochanek tej Żydówki, M. Édouard, nie ustaje w staraniach o jej uwolnienie [...]. Dlatego też proszę o zatrzymanie Żydówki Ariel w Drancy i jak najszybszą jej deportację, o ile nie zażąda jej wydania kraj, którego jest obywatelką. Dodaję, że M. udało się nawiązać kontakt z kochanką, a to za sprawą personelu Drancy. Kobieta codziennie otrzymuje listy i paczki i może pisać codziennie do kochanka” (ibidem, Kopia listu Antignaca do Röthkego, 1 VII 1943 r.).

${ }^{82}$ AN, Z 6, 1384, teczka 66, Akta Belli Ariel, Raport SEC z 21 VI 1943 r.

83 „Gdy poproszono, aby pokazała ubranie z gwiazdą, nie była w stanie tego uczynić i musiała przyznać, że tego dnia nie miała symbolu”. W efekcie zabrano ją na posterunek policji przy Saint-Vincent de Paul w Paryżu. Trafiła tam o 11.15. AN, Z 6, 1387, teczka 41, Raport SEC, 17 VI $1943 \mathrm{r}$.

${ }^{84}$ AN, Z 6, 1387, teczka 41, Donos podpisany przez Rogera F., 24 IV 1943 r. Donosiciel podał dwa adresy.

${ }^{85}$ Dwie bezskuteczne wizyty i dwa wezwania nie doprowadziły do zatrzymania kobiety. 25 V 1943 r. inspektorzy SEC zastali w końcu ofiarę w domu. Przesłuchali ją, kazali dokładnie 
SEC nie wpadliby też na trop rodziny, która tak dobrze ukrywała się od wydarzeń na Vel d’Hiv, gdyby nie donos:

Mam zaszczyt poinformować, że dowiedzieliśmy się, iż rodzina Mendelsohnów z bulwaru Ménilmontant 110 w Paryżu (20e), na którą wydano nakaz aresztowania 16 lipca 1942 r., ukrywała się u dozorczyni, a następnie uciekła do Villepinte (Seine-et-Oise), wreszcie ukryła się w swym mieszkaniu i nie opuszczała go, a jedzenie dostarczała wymienionym wspomniana dozorczyni.

Dwaj inspektorzy udali się do domu Żyda Mendelsohna i zastali go tam wraz $\mathrm{z}$ rodzina. [...]

Przekazaliśmy rodzinę Mendelsohn na Komisariat Policji Opera wczoraj, 15 stycznia 1943 r., o godzinie $19^{86}$.

W ten sposób podły donos położył kres nadziejom Benjamina i Tauby Mendelsohnów, polskich Żydów urodzonych w 1895 i 1896 r., oraz ich dwóch córek - Sary i Racheli, urodzonych w latach 1925 i 1929. Całą rodzinę wywieziono 11 lutego 1943 r. transportem nr 47. Nikt z nich nie przeżył.

Tych kilkaset przykładów, choć są stosunkowo nieliczne (poszukiwania w archiwach Policji Narodowej przyniosłyby ich bez porównania więcej), daje wyobrażenie o poważnych konsekwencjach, jakie w latach okupacji mógł mieć zwykły list zawierający donos. W tych kwestiach Komisariat Generalny Spraw Żydowskich, w zasadzie zajmujący się przejmowaniem dóbr, miał też prawo decydowania o życiu i o śmierci osób, które znalazły się w sferze jego zainteresowań.

Opierając się na przytoczonych przykładach, możemy stwierdzić, że donosy o charakterze antysemickim w latach 1940-1944 miały wiele cech pozwalających odróżnić je od innych rodzajów denuncjacji. Przede wszystkim wpisywały się one W mocno zakorzenioną tradycję polityczną skrajnej prawicy (rubryka w „La Libre Parole” od schyłku XIX w., broszury i pamflety mówiące o „wpływach Żydów” itp.), co wyjaśnia istnienie wielu instancji pośredniczących między „obywatelem-donosicielem” a władzami. Zazdrość i zawiść, podbudowane antysemickimi uprzedzeniami, stanowią główny motyw działania osób denuncjujących Żydów. Czysta, bezinteresowna, podła nienawiść odgrywa jednak ogromną rolę. Z tego punktu widzenia łatwiej zdefiniować donosy zwracające się przeciwko Żydom niż inne formy denuncjacji jako stanowiące przejaw lęków i nienawiści typowych dla rasizmu.

wypełnić kartę „Ustalenia cech żydowskich” itp. „Ponieważ niejaka Lechassagne zasłaniała się narodowością niemiecką, aby nie podlegać naszemu śledztwu, jej przypadek został zgłoszony służbom z ulicy Saussaies, z którymi nawiązaliśmy w tej sprawie kontakt. Wydali nam ustny rozkaz zatrzymania kobiety do ich dyspozycji. Douillet przekazał ją gestapo o 10.30" (AN, Z 6, 1387, teczka 41, Raport SEC z 25 V 1943 r.).

${ }^{86}$ AN, AJ 38, 203, Raport SEC dla Prefektury Policji w Paryżu, 16 I 1943 r. 
CGQJ był główną instytucją przyjmującą listowne donosy na Żydów w latach okupacji. Według moich szacunków, od roku 1941 do 1944 r. Komisariat odebrał do 20000 denuncjacji. Większości z nich nie wykorzystano, ale jest oczywiste, że znaczna część zbrodni SEC była następstwem donosów.

Należy jednak wyraźnie określić ramy pojęcia, które usiłowałem scharakteryzować. Czy każdy donos na Żyda musi mieć charakter działania antysemickiego? Czy takie pojmowanie nie prowadziłoby do wyolbrzymienia antysemityzmu (i jego przejawów) oraz do uproszczeń dotyczących treści donosu (który często zwracał się przeciwko innym grupom), a także portretu psychologicznego donosiciela? Czy nie jest tak, że za każdym donosem kryje się ta sama motywacja: frustracje spowodowane trudną sytuacją ekonomiczną w danym okresie, chęć zysku, zawiść, chęć podporządkowania się dominującym normom politycznym i udowodnienia postawy obywatelskiej i „narodowej” 87 itp.?

Na te wątpliwości, wszak zrozumiałe, można odpowiedzieć, odnosząc się właśnie do wykorzystanych przeze mnie materiałów i setek listów z archiwum Komisariatu Generalnego - niepodważalnym faktem jest, że to antysemici chwytali za pióro, by znając prawa i zakazy wymierzone w Żydów, „z radością” „demaskować” tych, którzy je naruszali. Nawet kilka przykładów Żydów denuncjujących innych Żydów potwierdza zakorzenienie antysemickich uprzedzeń.

Ci, którzy donosili na Żydów, być może „rozkoszowali się”, mogąc denuncjować innych „wrogów” reżimu i władz niemieckich - masonów, komunistów, „terrorystów” - i zwracali się do policji, milicji albo gestapo. Prawdę mówiąc, godnym gruntownego opracowania tematem jest historia donosu „politycznego” za okupacji, a na tym tle - donosy antysemickie.

Z języka francuskiego przełożyła Krystyna Szeżyńska-Maćkowiak

\title{
Słowa kluczowe
}

denuncjacja, Holokaust, Francja, Vichy

\begin{abstract}
The article shows the phenomenon of the denunciation of the Jews in France during World War II. Based on the data from the archives of the Commissariat général aux questions juives (CGQJ), i.e. the anti-Semitic institution of the Vichy government, it is estimated that the authorities received from 3 up to 5 million denouncements during 1940-1944. Special police units operated in the Paris region. They systematically verified the denunciations sent to the authorities, German army and anti-Semitic newspapers. The Jews were a group most often attacked in the denunciations.
\end{abstract}

${ }^{87} \mathrm{Na}$ ten temat por. przesłuchania i analizy Benna Williama, Letters of Denunciation in the Lyon Region, 1940-1944, „Historische Sozialforschung” 2001, t. 26, nr 2/3, s. 136-152. 
The propaganda and political activity as well as the number of bans put on them contributed to such frequent denunciations. The article described the specificity of the denunciations, their characteristics and the response of the authorities and the institutions they were sent to.

\section{Key words}

denunciation, Holocaust, France, Vichy 